\title{
Petechial purpuric rash after non-invasive blood pressure measurement: Rumpel-Leede sign
}

\author{
Bram Doron van Rhijn, ${ }^{1}$ Georgios Jannis Vlachojannis, ${ }^{2}$ \\ Deepak Mukesh Wieshwaykumar Balak'
}

${ }^{1}$ Department of Dermatology and Allergology, University Medical Center Utrecht, Utrecht, The Netherlands ${ }^{2}$ Department of Cardiology, University Medical Center Utrecht, Utrecht, The Netherlands

Correspondence to Dr Deepak Mukesh Wieshwaykumar Balak; balak.dmw@gmail.com

Accepted 25 September 2019

\section{DESCRIPTION}

A 62-year-old man with a history of hypertension, hypercholesterolaemia, myocardial infarction and chronic renal failure was admitted at the cardiac care unit after having undergone a percutaneous coronary intervention (PCI) for a ramus circumflex artery stenosis earlier that morning. Based on the patient's clinical presentation with an acute coronary syndrome/non-ST segment elevation myocardial infarction, he had been started-in addition to his chronic aspirin treatment-on ticagrelor pre-PCI. During heart catheterisation he had received a bolus of 5000 International Unit (IU) of heparin at the start of the procedure, and an additional 2500 IU of heparin before proceeding to ad-hoc PCI.

The heart catheterisation procedure was performed via the right radial artery, and initial haemostasis at access site was achieved by placement of a radial artery compression band (Rayband; Lepu Medical, Beijing). As per protocol, the compression band was at first inflated with $12 \mathrm{~mL}$. Due to a subcutaneous bleed and haematoma forming next to the initially placed radial artery compression band, a second radial band was placed adjacent to the first band at the proximal side, successfully suppressing further growth of the haematoma. The radial band

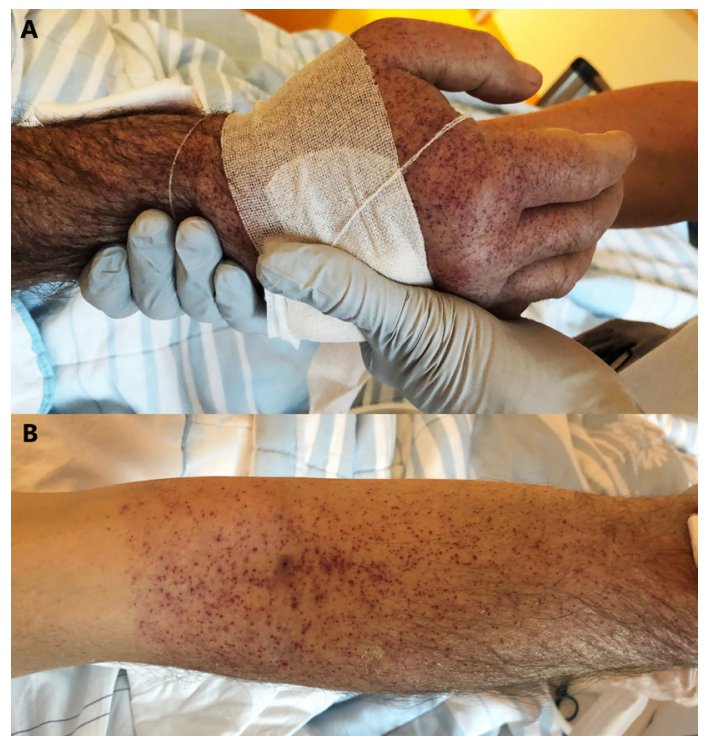

Figure 1 Disseminated fine macular petechiae and nonpalpable purpura without ulceration on the right lower arm and hand (A). The upper boundary of the petechial rash was rather well demarcated at the antecubital fossa (B).

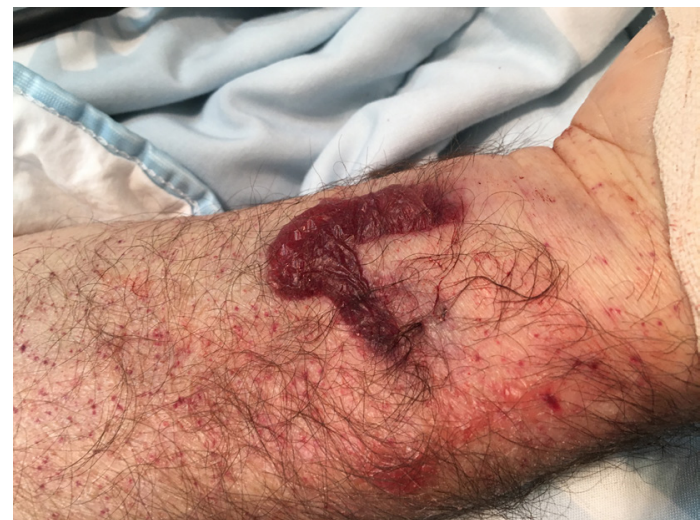

Figure 2 Haemorrhagic bulla at the site of the radial puncture.

deflation protocol was followed for both applied devices, with deflation after $30 \mathrm{~min}$ until pulsation/ flow was visible while still achieving haemostasis; after another $30 \mathrm{~min}$ and then after $60 \mathrm{~min}$, the compression bands were further deflated by $2 \mathrm{~mL}$, respectively, with complete deflation and removal of the bands after 2 hours.

Several hours later, the patient developed a non-blanching rash immediately following inflating a sphygmomanometer cuff for blood pressure measurement. On examination, the patient had multiple fine petechiae and non-palpable purpura scattered around the right lower arm (figure 1). Remarkably, the upper boundary of the petechial rash was well demarcated at the antecubital fossa, closely following the lower border of the sphygmomanometer cuff. Except for a haemorrhagic bulla at the radial puncture site (figure 2), no other skin lesions or symptoms were present.

These findings are consistent with a clinical diagnosis of tourniquet-induced petechiae, first described by Theodor Rumpel in 1909 and Carl Stockbridge Leede in 1911 in patients suffering from scarlet fever, hence also known as the 'RumpelLeede sign'. This clinical phenomenon refers to the acute development of a petechial rash distally from a cuff typically applied to the upper arm. ${ }^{1}$ The petechiae are a result of acute rupture of the dermal capillaries, signifying microvascular fragility. ${ }^{2}$ The Rumpel-Leede sign was formerly used to evaluate for thrombocytopaenia and other bleeding tendencies, and is nowadays still used infrequently for analysis of haemorrhagic manifestations in dengue fever (referred to as tourniquet test) and encountered in patients with immune thrombocytopaenic purpura. ${ }^{3}$ It has also been described following 


\section{Learning points}

- The Rumpel-Leede sign refers to the acute development of a petechial rash distally from a cuff typically applied to the upper arm and is caused by acute rupture of the dermal capillaries, signifying microvascular fragility.

- Tourniquet-induced petechiae can be accidentally encountered with non-invasive blood pressure measurement in patients having an increased risk for capillary fragility, such as haemodialysis and antiplatelet therapy.

- Recognition of this self-limiting clinical phenomenon is important to avoid unnecessary diagnostics.

radial artery catheterisation. ${ }^{5} 6$ Other predisposing factors include diabetes mellitus and hypertension. Our patient had normal platelet counts, making the petechiae likely attributed to microvascular fragility related to hypertension and chronic renal failure requiring haemodialysis, in addition to the increased intracapillary pressure due to cuff compression. ${ }^{27}$ Additionally, the patient's aspirin and ticagrelor treatment impacting platelet function may have contributed to the petechial purpuric rash. ${ }^{8}$ In view of the benign characteristics of the rash and the indication for potent platelet inhibition in the setting of an acute coronary syndrome with subsequent PCI, we did not adjust dual antiplatelet therapy.

Interestingly, in this patient, the rash did not occur after placement of the radial compression band, probably because it was inflated just enough to achieve haemostasis while allowing arterial flow past the compressed segment, a condition called 'patent haemostasis'. In contrast, inflation of the sphygmomanometer led to a temporarily complete occlusion of the arterial circulation with subsequent acute release of arterial flow, which posed the classic trigger of the Rumpel-Leede sign. The bulla that developed at the radial access site is likely more related to the radial artery compression tourniquet device.

As the Rumpel-Leede sign can accidentally be encountered with non-invasive blood pressure measurement in patients at risk for capillary fragility, recognition of this self-limiting clinical phenomenon is important to avoid unnecessary diagnostics. In this patient, the petechial rash resolved completely without any sequelae within several weeks.

\section{Twitter Bram Doron van Rhijn @RhijnB}

Contributors BDvR wrote the manuscript. GJV and DMWB provided care for the patient and provided critical revision of the manuscript. BDvR, GJV and DMWB approved the final manuscript.

Funding The authors have not declared a specific grant for this research from any funding agency in the public, commercial or not-for-profit sectors.

Competing interests None declared.

Patient consent for publication Obtained.

Provenance and peer review Not commissioned; externally peer reviewed.

\section{REFERENCES}

1 Wang K, Lee J. Images in clinical medicine. Rumpel-Leede sign. N Eng/ J Med 2014;370:e1.

2 Chester MW, Barwise JA, Holzman MD, et al. Acute dermal capillary rupture associated with noninvasive blood pressure monitoring. J Clin Anesth 2007;19:473-5.

3 Grande AJ, Reid H, Thomas E, et al. Tourniquet test for dengue diagnosis: systematic review and meta-analysis of diagnostic test accuracy. PLoS Negl Trop Dis 2016;10:e0004888.

4 Dubach P, Mantokoudis G, Lämmle B. Rumpel-Leede sign in thrombocytopenia due to Epstein-Barr virus-induced mononucleosis. Br J Haematol 2010;148:2.

5 Khoury Abdulla R, Safian RD. Rumpel-Leede phenomenon after radial artery catheterization. Circ Cardiovasc Interv 2018;11:e006507.

6 Rattka M, Rottbauer W. Rumpel-Leede sign after coronary angiography. Dtsch Arzteb/ Int 2018;115

7 Lee S, Jang YB, Kang KP, et al. Rumpel-Leede phenomenon in a hemodialysis patient. Kidney Int 2010;78:224.

8 Pritchard AE, Lockhart EL. Rumpel-Leede phenomenon in a patient being treated with prasugrel. Transfusion 2017;57:1642.

Copyright 2019 BMJ Publishing Group. All rights reserved. For permission to reuse any of this content visit

https://www.bmj.com/company/products-services/rights-and-licensing/permissions/

BMJ Case Report Fellows may re-use this article for personal use and teaching without any further permission.

Become a Fellow of BMJ Case Reports today and you can:

- Submit as many cases as you like

- Enjoy fast sympathetic peer review and rapid publication of accepted articles

- Access all the published articles

Re-use any of the published material for personal use and teaching without further permission

Customer Service

If you have any further queries about your subscription, please contact our customer services team on +44 (0) 2071111105 or via email at support@bmj.com.

Visit casereports.bmj.com for more articles like this and to become a Fellow 